\title{
Effectiveness of Ageratum conyzoides (Babandotan) Leaf Extract and Sapindus rarak (Lerak) Fruit Extract in Control of Myzus persicae in Chili Plants
}

\author{
Djamilah $^{1 *}$, Umm Ro'ina Rosyada ${ }^{2}$, and Yudhi Harini Bertham ${ }^{3}$ \\ ${ }_{1}$ Plant Protection University of Bengkulu \\ ${ }_{2}^{2}$ Agroecotechnology $\mathrm{y}_{\iota}$ University of Bengkulu \\ ${ }_{3}$ Soil Science, University of Bengkulu \\ *Coresponding author: djamilah@unib.ac.id
}

\begin{abstract}
Chili is one of the important agricultural commodity in Indonesia. Myzus persicae Sulz. is one of the important pests in Chili cultivation because it can cause damage up to $80 \%$. Nabati insecticide utilization is one of the safer alternatives to control and more environmentally friendly than synthetic insecticides. One Nabati insecticide utilization that can be used in controlling pests are Ageratum conyzoides L extract and Sapindus rarak D.C extract. The purpose of this study was to determine the effectiveness of A. conyzoides extract, $S$. rarak extracts and extract $S$. rarak mixture of both in the control of $M$. persicae. This research was factorial, treatment consisted of 2 factors: 1 Nabati insecticide consists of $A$. conyzoides and S. rarak and factor of 2 each given concentration is $0 \%, 1 \%, 2 \%, 3 \%$. Using a completely randomized design (CRD) with 16 treatments 3 replications. The results variance showed that the treatment performed with extracts from A. conyzoides effect on mortality, damage to crops, $M$. persicae population, and leaf greenness level after treatment. Extract treatment $S$. rarak affects on mortality, $M$. persicae population and leaf greenness level after treatment. While treatment mix A. conyzoides leaf extracts and fruit extracts $S$. rarak effect on mortality, M. persicae population. The results showed that the treatment is effective in controlling pests aphids $M$. persicae are A. conyzoides leaf extract mixture of $3 \%$ and $3 \% S$. rarak fruit extract with the highest mortality value of $96.14 \%$, which gives a real influence in the control of aphids M. persicae and different real control. LC50 and LC90 showed the best application in the control extract are $18.46 \mathrm{ml}$ and $51.86 \mathrm{ml}$.
\end{abstract}

Key words: Nabati (plant extract) insecticide Utilization, Myzus persicae, Chili

Citation to this paper should be made as follows:

Djamilah, U. R. Rosyada, and Y. H. Bertham. 2021. Effectiveness of Ageratum conyzoides (Babandotan)

Leaf Extract and Sapindus rarak (Lerak) Fruit Extract in Control of Myzus persicae in Chili Plants.

Agritropica: Journal of Agricultural Science. 4 (1): 63-74. DOI:

https://doi.org/10.31186/Jagritropica.4.1.63-74.

\section{INTRODUCTION}

Red chili (Capsicum annum L.) is an essential vegetable which is highly economical and is favored by Indonesian people. Chili contains many nutrients and vitamins, such as calories, protein, fat, carbohydrates, calcium, vitamin A, vitamin B1, and vitamin C (Setiadi, 2002). The high demand for this commodity necessitates an increase in production not only in terms of quantity but also in terms of quality. The problems that exist in red chili plants are not only limited to cultivation problems, but how to deal with pests and diseases of red chili plants (Setiadi, 2002).

One of the important pests in red chili plants is M. persicae (Kalshoven, 1981). Aphids (M. persicae) can reduce the quality and quantity of chili production. These pests eat all types of plants (polyphages). 
M. persicae attack can cause curly leaves, wrinkled shoots that stunted plant growth. In severe attacks it can cause the leaves to fall off and eventually die (Dafrinal et al, 2012).

According to Herlinda et al. (2009) M. persicae pests cause damage by puncturing the tissue and sucking the leaf cell fluid which results in abnormal leaf growth and the affected leaves become brittle. Another damage caused by $M$. persicae is the formation of sooty moisture due to the presence of a sweet liquid produced by $M$. persicae, which affects the photosynthesis process. The losses caused by $M$. persicae as a pest ranged from $6-25 \%$ and as a vector can reach losses of more than $90 \%$.

The population density of $M$. persicae and the level of leaf damage by $M$. persicae has a close relationship with the loss of yield of red chilies (Sudarjat, 2008). So it is necessary to do effective control, one of which is using vegetable insecticides that can be obtained from plants, including weeds. The use of vegetable insecticides as pest control has received a lot of attention to be developed because it is relatively easy to obtain, safe for non-target animals and easily decomposes in nature leaving no environmental pollution, the residue is relatively short, and pests don't develop to become resistant to vegetable insecticides (Oka, 1993).

Several types of vegetable insecticides are able to control M. persicae, including soursop leaves (Annona muricata L.), neem leaves (Azadirachta indica J.), papaya leaves (Carica papaya L.), and babandotan (Ageratum conyzoides L.) (Astriani, 2010).

The leaves of $A$. conyzoides contain pyrolizidin alkaloida compounds with chemical structures in the form of Lycopsamin and Echinatin, which have been developed as vegetable pesticides although they are still on a limited scale (Kinasih et al., 2013). In the classification, this plant includes flowering plants, members of the Asteraceae family. In Indonesia A. conyzoides is one of the most disturbing plants, it can live in fields, yards, gardens, and roadsides (Gainge dan Ahmed, 1988).

A. conyzoides extract has been used in Widiastuti and Shinta's (2008) research on house flies (Musca domestica). The results of $A$. conyzoides extract are effective in killing house flies. In addition, research by Purnama et al. (2016) reported that $A$. conyzoides leaf extract was able to inhibit the growth of the stink bug (Leptocorisa acuta), with various concentrations indicating that the higher the concentration given, the higher the mortality of the pest.

Another plant that has the potential to be used as a source of vegetable insecticides is lerak fruit (Sapindus rarak D.C.) (Heyne 1987). The content of compounds found in $S$. rarak pulp includes triterpene, alkaloids, steroids, anthraquinones, tannins, flavonoids and saponins. S. rarak fruit extract contains saponins around 48.9\% (Sunaryadi, 1999). Saponins have distinctive characteristics, taste bitter, form stable foam in water, are toxic to cold-blooded animals, such as fish, snails and insects (Tekeli et al., 2007). Saponins are found in all parts of the $S$. rarak plant with the highest content found in the fruit (Widowati, 2003). According to Yanuar and Prijono (2013) in their research, S. rarak extract prepared with water, either singly or in mixture with forest betel fruit extract, is quite effective against larvae of Crocidolomia pavonana.

\section{Research purposes}

To determine the effectiveness of $A$. conyzoides leaf extract, $S$. rarak fruit and a mixture of both in controlling $M$. persicae in chili plants. 


\section{RESEARCH METHOD}

\section{Research Implementation}

The research was conducted at the Laboratory of Plant Protection and Screen Houses, Faculty of Agriculture, University of Bengkulu. This research was arranged factorial using a completely randomized design (CRD) with 16 treatments 3 times repetition. There were 48 plants for the experimental unit, consisting of:

Factor 1 = type of vegetable insecticide Ageratum conyzoides (B)

Sapindus rarak (L)

Factor 2 = Concentration of plant extract insecticides: $0 \%, 1 \%, 2 \%, 3 \%$

\section{Research stages}

Thousand gram of $A$. Conyzoides leaf extraction were used. $A$. Conyzoides leaf extract was prepared by using the crude extract method by blending it directly. Previously, A. Conyzoides leaves were washed and dried to dry, after which 1000 $\mathrm{g}$ of $A$. Conyzoides leaves were sufficiently dry, added with $1000 \mathrm{ml}$ of water, blended until smooth. Furthermore, the solution is transferred to the beaker and then allowed to stand for 24 hours. After 24 hours the solution was stirred and filtered using a filter cloth, and obtained as much as \pm 1000 $\mathrm{ml}$ as the main solution. The preparation of S. rarak fruit extract was carried out by separating the pulp and seeds. $1000 \mathrm{~g}$ of $S$. rarak pulp is blended by adding $1000 \mathrm{ml}$ of water. Furthermore, the solution was transferred to a beaker and let stand for 24 hours. After 24 hours, the solution was stirred and filtered using a filter cloth, and obtained as much as $\pm 1000 \mathrm{ml}$ as the main solution. The concentrations used in the test were $1 \%, 2 \%$, and $3 \%$.

M. persica is infused into each plant as many as 30 individuals / plant. Pest infestation is carried out when the plants are 4 weeks after planting in the polybags.

The application of botanical insecticides was carried out 24 hours after $M$. persicae was infused on the plant. The application of vegetable insecticide spraying was carried out in the afternoon using a hand sprayer containing a solution of $A$. conyzoides extract, $S$. rarak extract and extracts from the mixture of the two, with a concentration according to the treatment to be carried out. Spraying is done once, with a spray volume of $12 \mathrm{ml} /$ plant. Observations were made after 24 hours of application, daily for one week.

\section{Observation Variable}

a. Mortality of $M$. persicae. Mortality observations of $M$. persicae were carried out every day for one week after application of the extract.

Mortality is calculated using the formula (Natawigena, 1993):

$$
\text { Mortality }=\frac{a}{a+b} \times 100 \%
$$

Note: $\mathrm{a}=$ number of dead $M$. persicae, $\mathrm{b}=$ number of living $M$. persicae

a. Scoring damage to crops, observations carried out one time during the week to count the leaves were affected, with criteria yellow, curl, and wrinkle. Table 1. Value and category of infestation by aphids (Natawigena, 1993)

\begin{tabular}{rlll}
\hline Score & \multicolumn{1}{c}{ Category } & Percentage & Attack category \\
\hline 0 & There is no attack on the leaves & 0 & Normal \\
1 & 1-5 parts of the leaf roll & $>0-25$ & Light \\
2 & 6-10 leaf sections curled & $>25-50$ & Moderate \\
3 & $11-15$ curled leaf sections & $>50-75$ & Weight \\
4 & $>16$ sections rolled & $>75$ & Very heavy \\
\hline
\end{tabular}


b. Changes in behavior and morphology of $M$. persicae, by observing the movement and color of $M$. persicae due to treatment. Observations were made once a day for 1 week after the extract was applied.

c. The number of $M$. persicae that is still alive, observations were made after spraying / application of the extract, done once a day for 1 week.

d. The level of greenness of the leaves, observations were made 2 times using a chlorophyll meter (SPAD) before the extract application and at the end of the study. The observations were repeated 2 times on the 4th and 5th leaves.

\section{Data analysis}

The data were analyzed with ANOVA variance level of $5 \%$, if $h$ a sill significant effect was tested further by using (DMRT) and probit analysis using Minitab.16 program to determine the value of $\mathrm{LC}_{50}$ and $\mathrm{LC}_{90}$

\section{RESULTS AND DISCUSSION}

Observation variables for treatment of $A$. conyzoides leaf extract and $S$. rarak fruit extract on chili plants

Results of analysis of variance observation variable treatment of extracts of leaves of $A$. conyzoides and extract fruit $S$. rarak on planting an chili served on table 2 .

Table 2. Analysis of variance of observed for chilli plants and Myzus persicae Sulz

\begin{tabular}{clccc}
\hline No. & \multicolumn{1}{c}{ Items } & $\begin{array}{c}\text { A. conyzoides } \\
\text { leaf extract }\end{array}$ & $\begin{array}{c}\text { S. rarak fruit } \\
\text { extract }\end{array}$ & Interaction \\
\hline 1 & Mortality & $34,84^{* *}$ & $46,63^{* *}$ & $8,32^{* *}$ \\
2 & Damage scoring & $26,66^{* *}$ & $4,44^{*}$ & $2,66^{*}$ \\
3 & M. persicae population & $192,43^{* *}$ & $127,95^{* *}$ & $3,90^{* *}$ \\
4 & Green Leaf I & $0,83^{\text {ns }}$ & $0,56^{\text {ns }}$ & $1,09^{\text {ns }}$ \\
5 & Green Leaf II & $17,01^{* *}$ & $9,03^{* *}$ & $12,79^{* *}$ \\
\hline
\end{tabular}

Note: ${ }^{*}=$ Significantly different at the $5 \%$ level test, $"=$ very significantly different at the $1 \%$ level, ns $\mathrm{T}=$ Not significantly different

The results of the analysis of variance showed that babadotan leaf extract, S. rarak fruit extract and mixed extract significantly affected the mortality of $M$. persicae, M. persicae population and leaf greenness levels after treatment. The single treatment of babadotan leaf extract influenced mortality, plant damage, $M$. persicae population, and leaf greenness after treatment. In single treatment, S. rarak fruit extract affected mortality, M. persicae population and leaf greenness after treatment. While the treatment of a mixture of babadotan leaf extract and $S$. rarak fruit extract has an effect on mortality,
M. persicae population.To evaluation the effect of the extract on the observed variables can be seen in the Duncan's Multiple Range Test (DMRT). The DMRT test results showed that single and mixed extract treatments had a significant effect on mortality and M. persicae population.

The average percentage of $M$. persicae mortality in tests using $A$. conyzoides leaf extract and $S$ rarak fruit extract is presented in Table 3 . The results showed that in general the mortality of $M$. persicae was higher along with the increase of concentrations of $A$. conyzoides leaves extract and $S$. rarak fruit extract . 
Table 3. Average interactions of A. conyzoides leaf extract and S. rarak fruit extract on mortality of $\mathrm{M}$. persicae

\begin{tabular}{ccccc}
\hline \multirow{2}{*}{ Treatment } & \multicolumn{4}{c}{ Mortality (\%) } \\
\cline { 2 - 5 } & S.rarak 0\% & S.rarak 1\% & S.rarak 2\% & S.rarak 3\% \\
\hline A.conyzoides 0\% & $0,20 \mathrm{Aa}$ & $59,05 \mathrm{Ab}$ & $72,26 \mathrm{AC}$ & $78,00 \mathrm{AD}$ \\
A.conyzoides 1\% & $64,00 \mathrm{Ba}$ & $70,74 \mathrm{Bb}$ & $80,38 \mathrm{BC}$ & $83,01 \mathrm{BC}$ \\
A.conyzoides 2\% & $77,26 \mathrm{Ca}$ & $79,15 \mathrm{Cb}$ & $82,51 \mathrm{BB}$ & $84,98 \mathrm{BB}$ \\
A.conyzoides 3\% & $79,09 \mathrm{Ca}$ & $86,63 \mathrm{Db}$ & $90,20 \mathrm{CB}$ & $96,14 \mathrm{CC}$ \\
\hline
\end{tabular}

Note: The numbers followed by the same letter in the same column / row show no significant difference in the DMRT follow-up test at the $5 \%$ level. (Letters large on the column are equally readable for comparing the extract of the fruit of S. rarak and letters little on the line that equally readable for comparing extracts of leaves of A. conyzoides).

The results of the statistical test using $S$. rarak fruit extract only can increase the mortality of $M$. persicae from a concentration of $1 \%$ to a concentration of 3 $\%$. Meanwhile, A. conyzoides leaf extract only at a dose of $2 \%$ was able to increase the mortality of $M$. persicae. Thus, $A$. conyzoides leaf extract is more effective than S. rarak fruit extract. In the $1 \% A$. conyzoides treatment, the effectiveness increased when mixed with $2 \%$ of $S$. rarak, while the use of $2 \% A$. conyzoides mixed with $1 \%$ of S. rarak had shown good effectiveness. But the A. conyzoides extract with a concentration of $3 \%$ was the most effective at killing $M$. persicae when mixed with $3 \%$ of $S$. rarak. Thus the highest mortality was achieved when $3 \%$ of $A$. conyzoides leaf extract was mixed with $3 \%$ of $S$. rarak fruit extract.

Referring to table 3,The statistical test of plant extract pesticides had a significant effect on the mortality of $M$. persicae. In general, it can be seen that the treatment given $A$. conyzoides leaf extract, $S$. rarak fruit extract and mixed extract at various concentrations resulted in the mortality of $M$. persicae increasing with the high concentration given. In the extract treatment given caused $M$. persicae mortality of more than $50 \%$. The highest mortality was found in the treatment of a mixture of $3 \%$ A. conyzoides leaf extract and $3 \%$ of $S$. rarak fruit extract (B4L4), which caused a mortality of $96.14 \% \mathrm{M}$. persicae.

In table 3 , treatment of $A$. conyzoides extract containing saponins, flavonoids and polyphenols, and fruit extracts of $S$. rarak containing alkaloids, triterpenes, steroids, and saponins, which are effective in protecting plants from pests have toxic power against $M$. persicae, and are compatible (suitable) so that it is synergistic, that is, when the two extracts are mixed it will produce better results. The results showed that the testing of $A$. conyzoides leaf extract, $S$. rarak fruit extract and a mixture of both had a very significant effect on the mortality of $M$. persicae. $M$. persicae which died from poisoning caused by the contents of the two extracts which is characterized by the body being stiff and blackish-brown in color. Saponins have a characteristic bitter taste and are toxic to insects (Tekeli et al, 2007). Purba (2007) states that an increase in dosage is directly proportional to the increase in toxic substances, so that the killing power is higher.

After the application of plant extract insecticides, aphids $M$. persicae become swirling, and rarely moving, grows progressively weaker and then die. Its body become stiff and blackish brown in colour 

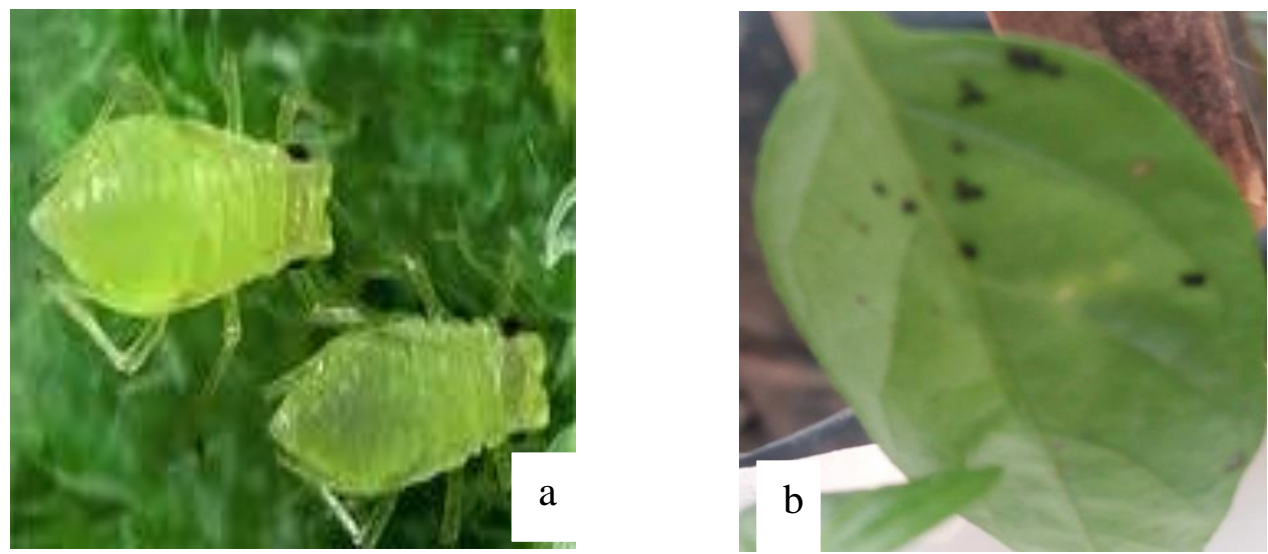

Figure 1. M. persicae

a. M. persicae healthy, b. M. persicae death

The surviving $M$. persicae after the extract application is presented in table 4 . The use of $S$. rarak fruit extract showed effectiveness at a concentration of $2 \%$, leaving 30 surviving $M$. persicae. Meanwhile, the use of $A$. conyzoides leaf extract fruit extract effectiveness at a concentration of $3 \%$ left $M$. persicae still alive. The mixed use of the two kinds of extracts showed that the dose of $1 \% A$. conyzoides leaf extract mixed with $2 \%$ of $S$. rarak fruit extract was more effective than 1 $\%$ of $S$. rarak fruit extract. But the dosages of $2 \%$ and $3 \%$ A. conyzoides leaf extract were more effective by leaving the lowest $M$. persicae without a mixture of $S$. rarak fruit extract. Thus, $A$. conyzoides leaf extract was more effective at reducing the number of live $M$. persicae at a dose of $2 \%$.

Tabel 4. The average interaction of $A$. conyzoides leaf extract and $S$. rarak fruit extract on the live population of M. persicae on chili plants.

\begin{tabular}{ccccc}
\hline \multirow{2}{*}{ Treatment } & \multicolumn{4}{c}{ Population M. persicae ( tail ) } \\
\cline { 2 - 5 } & S.rarak 0\% & S.rarak 1\% & S.rarak 2\% & S.rarak 3\% \\
\hline A.conyzoides 0\% & $159,38 \mathrm{Aa}$ & $39,67 \mathrm{AB}$ & $30,14 \mathrm{Ac}$ & $28,05 \mathrm{Ac}$ \\
A.conyzoides $1 \%$ & $41,57 \mathrm{Ba}$ & $35,67 \mathrm{AA}$ & $23,28 \mathrm{Ab}$ & $20,04 \mathrm{Ab}$ \\
A.conyzoides $2 \%$ & $22,14 \mathrm{Ca}$ & $21,05 \mathrm{BA}$ & $20,24 \mathrm{Aa}$ & $18,90 \mathrm{Aa}$ \\
A.conyzoides 3\% & $14,25 \mathrm{Da}$ & $13,04 \mathrm{BA}$ & $10,76 \mathrm{Aa}$ & $6,15 \mathrm{Ba}$ \\
\hline
\end{tabular}

Note : The numbers followed by the same letter in the same column / row show no significant difference in the DMRT follow-up test at the 5\% level. (uppercase letters in the same column are read to compare S. rarak fruit extracts and lowercase letters in the same row are read to compare A. conyzoides leaf extracts).

Based on Table 4. Treatment of application of $A$. conyzoides extract and $S$. rarak fruit extract tended to reduce the number of living population of $M$. persicae until the fourth day of observation. On the 5 th, 6 th, and 7 th days there was an increase in the number of $M$. persicae population in chili plants, due to the effect of decreasing / missing chemical content in plants (Figure 2).
The increase in the number of $M$. persicae can be caused by the residue in the pesticide which is easily broken down due to hot weather. According to Syakir (2011), Biopesticides can kill or disturb plant pests (OPT) through a combination of two different insecticides and singly, besides these advantages, plant extract insecticides also have disadvantages such as being easily damaged and not resistant to 
exposure to sunlight. cause the vegetable insecticide to degenerate easily.

Referring to Figure 2, it shows that the mixture of $A$. conyzoides leaf extract and $S$. rarak fruit is very good compared to the single extract of $A$. conyzoides leaves and $S$. rarak fruit. The effectiveness of the extracts of A. conyzoides leaves and S. rarak fruit in reducing $M$. persicae populations until day 4. On the fifth day, there was an increase in the population of $M$. persicae due to the reproduction of the remaining nymphs in the plant. $M$. persicae is very fast breeding. According to Srivivasan (2009) a female $M$. persicae will produce 20 nymphs every day and will mature in one week.

\section{M. persicae Population}

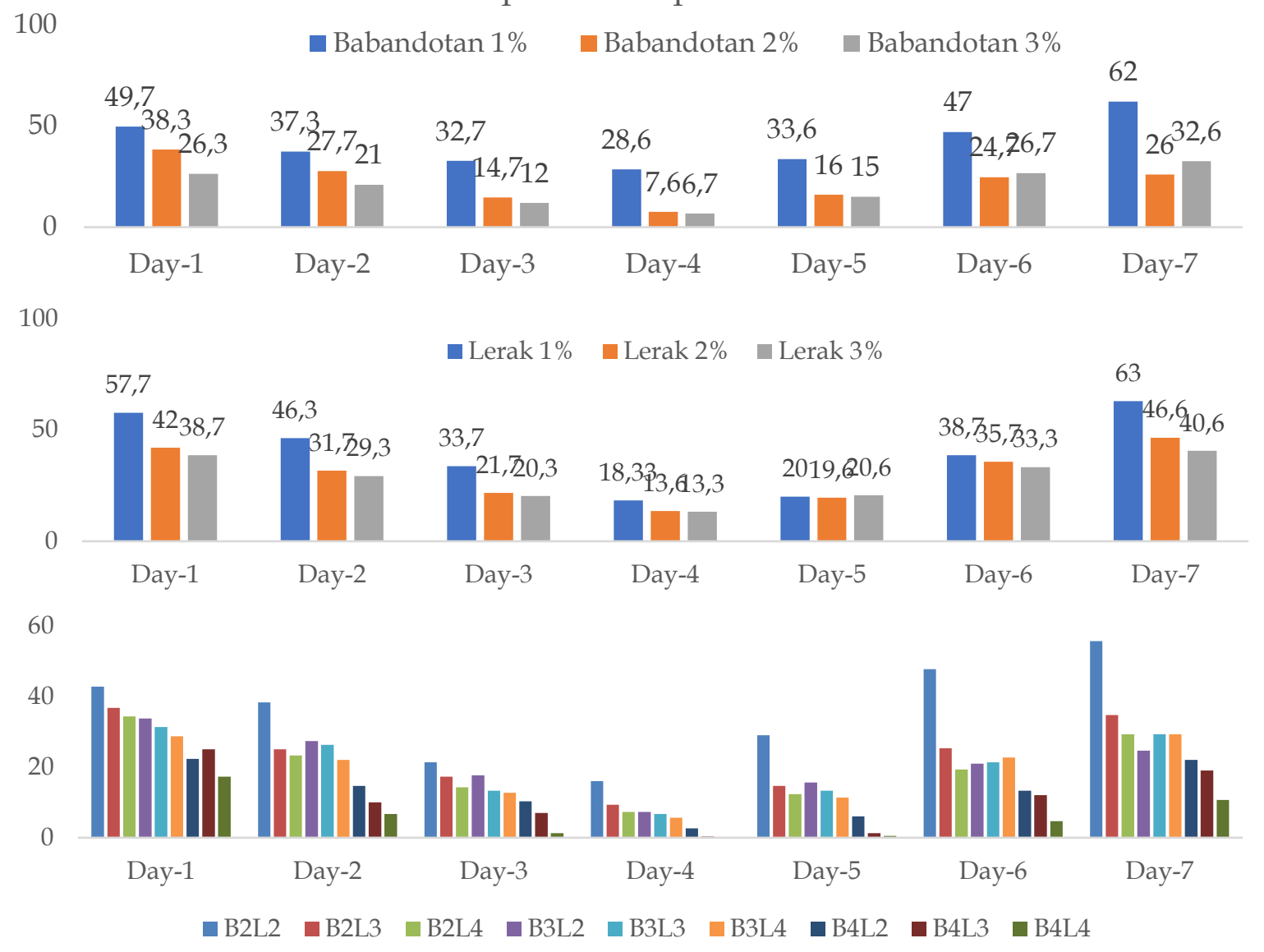

Note: $\mathrm{B}=$ A. conyzoides $; \mathrm{L}=S$. rarak; $2=1 \% ; 3=2 \% ; 4=3 \%$

Figure 2. M. persicae Population

The population of $M$. persicae was seen to increase from day 5 to day 8 . This is because the residues of $A$. conyzoides leaf extract and $S$. rarak fruit extract have been lost from the plant, so that it is no longer an inhibiting factor for the growth of $M$. persicae. Yolanda (2013) states that vegetable pesticides have properties that are easily biodegradable, are not resistant to the sun and must be applied repeatedly. So it is necessary to spray repeatedly to suppress the growth / reproduction of $M$. persicae. 
Tabel 5. The mean score of plant damage after the application of A. conyzoides leaf extract and $S$. rarak fruit extract

\begin{tabular}{lllll}
\hline \multirow{2}{*}{ Treatment } & \multicolumn{4}{l}{ Population M. persicae (tail ) } \\
\cline { 2 - 5 } & S.rarak 0\% & S.rarak 1\% & S.rarak 2\% & S.rarak 3\% \\
\hline A.conyzoides 0\% & $3,67 \mathrm{Aa}$ & $3,67 \mathrm{AA}$ & $2,67 \mathrm{Ab}$ & $2,67 \mathrm{Ab}$ \\
A.conyzoides 1\% & $3,00 \mathrm{Ba}$ & $3,00 \mathrm{AA}$ & $3,00 \mathrm{Aa}$ & $3,00 \mathrm{Aa}$ \\
A.conyzoides 2\% & $2,33 \mathrm{Ba}$ & $2,33 \mathrm{AA}$ & $2,67 \mathrm{Aa}$ & $2,00 \mathrm{Aa}$ \\
A.conyzoides 3\% & $2,00 \mathrm{Ba}$ & $2,00 \mathrm{BA}$ & $2,00 \mathrm{Aa}$ & $2,00 \mathrm{Aa}$ \\
\hline
\end{tabular}

Note: The numbers followed by the same letter in the same column / row show no significant difference in the DMRT follow-up test at the 5\% level. (uppercase letters in the same column are read to compare S. rarak fruit extracts and lowercase letters in the same row are read to compare $A$. conyzoides leaf extracts).

The results of statistical tests show that the use of $S$. rarak fruit extract without $A$. conyzoides leaf extract can suppress plant damage at a concentration of $2 \%$ with moderate damage category (2.67), which is more effective than $S$. rarak $1 \%$ with severe damage category (3.67). In the treatment of $A$. conyzoides leaf extract without $S$. rarak mixture, the effectiveness range was seen in the $1 \%$ A. conyzoides leaf extract with severe damage category (3.00) which was no different from 2 and $3 \%$ with moderate damage category, respectively 2.33 and 2,00 . This makes babandotan leaf extract more effective in suppressing plant damage. A mixture of $1 \%$ of $S$. rarak extract and 3 $\%$ of A. conyzoides extract with moderate damage category (2.00) was more effective than $2 \% A$. conyzoides extract with severe damage category (3.00).

Referring to Table 5 . the effectiveness of the extract given is able to suppress plant damage, because it can interfere with the stages of the insect development process so that it does not develop and even dies. Prijono (1999) states that the antijuvenill hormone contained in $A$. conyzoides interferes with the stages of the development process in insects. Plant damage is closely related to mortality, the higher the concentration given, it shows that the mortality of $M$. persicae is higher and the damage to plants is lower. Other research states that the use of $A$. conyzoides extract and siam weed extract can reduce the intensity of the stink bug attack on rice plants (Purnama, 2016).

Table 6. Average levels of leaf 1 and 2 leaf greenness in the application of $A$. conyzoides leaf extract and $S$. rarak fruit extract on chili plants.

\begin{tabular}{lllllllll}
\hline \multirow{2}{*}{ Treatment } & \multicolumn{2}{l}{ Green level 1 } & \multicolumn{7}{c}{ Green level 2 } \\
\cline { 2 - 9 } & L1 & L2 & L3 & L4 & L1 & L2 & L3 & L4 \\
\hline B1 & 44,30 & 42,1 & 37,36 & 43,56 & 38,63 AA & 37,26 BA & 31,83 BA & 37,93 BA \\
B2 & 40,80 & 45,13 & 44,13 & 41,60 & 36,00 BA & 39,93 BA & 39,56 BA & 37,00 BA \\
B3 & 47,10 & 41,26 & 45,1 & 41,40 & 42,26 BA & 36,73 BA & 39,73 BA & 35,76 BA \\
B4 & 43,06 & 38,67 & 41,90 & 40,50 & 36,20 BA & 33,66 BA & 35,76 BA & 35,13 BA \\
\hline
\end{tabular}

Note $: \mathrm{B}=$ A. conyzoides; $\mathrm{L}=$ S. rarak; $1=0 \% ; 2=1 \% ; 3=2 \% 1 ; 4=3 \%$, the numbers followed by the same letter in the same column / row show no significant difference in the DMRT follow-up test at the $5 \%$ level. (uppercase letters in the same column are read to compare S. rarak fruit extracts and lowercase letters in the same row are read to compare A. conyzoides leaf extracts). 
Referring to table 6, the level of greenness of the leaves before treatment showed no significant effect, this was due to the absence of plant pests (OPT). differ in the level of greenness of the leaves after treatment. The treatment of $A$. conyzoides leaf extract with various concentrations showed no significant difference. The same thing happened in the treatment of $S$. rarak fruit extract with various concentrations, showing results that were not significantly different, but different from the control.

High leaf greenness is one of the factors that indicates that a plant is healthy. Leaf greenness can be affected by the presence of pests that can cause damage to plants. $M$. persicae is one of the pests that are very detrimental to plants, $M$. persicae can cause plant leaves to turn yellow, wrinkled and curl, so that plant growth is inhibited. A. conyzoides leaf extract, S. rarak fruit extract and a mixture of $A$. conyzoides leaf extract and $S$. rarak fruit extract given were able to control $M$. persicae, but the effectiveness of the A. conyzoides leaf extract and $S$. rarak fruit extract only lasted until the 4th day. The increase in the live population of $M$. persicae occurred on the 5th day continuously. El-khawas (2008) stated that aphids attack can cause a significant reduction in metabolic content, including chlorophyll.

\section{Determination of LC50 and LC90}

The effectiveness of $A$. conyzoides leaf extract, $S$. rarak fruit extract and a mixture of both in controlling $M$. persicae with the extract given is known from the LC50 and LC90 values, to determine the optimal concentration needed to control $50 \%$ and $90 \%$ of the tested insects.

Table 7. Effective concentrations of LC50 and LC90 in the application of A. conyzoides leaf extract, S. rarak fruit extract and a mixture of both

\begin{tabular}{lcl}
\hline Extract Solution & LC50 & LC90 \\
\hline A. conyzoides leaf & $5,19 \mathrm{ml}$ & $49,10 \mathrm{ml}$ \\
S. rarak fruit & $13,30 \mathrm{ml}$ & $73,50 \mathrm{ml}$ \\
A mixture of A. conyzoides leaf + S. rarak fruit & $18,46 \mathrm{ml}$ & $51,86 \mathrm{ml}$ \\
\hline
\end{tabular}

Referring to Table 7 , the results showed that to kill $50 \%$ and $90 \%$ of the tested pests, the $A$. conyzoides leaf extract required $5.19 \mathrm{ml}$ and $49.10 \mathrm{ml}$, the $S$. rarak fruit extract was given $13.3 \mathrm{ml}$ and $73.5 \mathrm{ml}$. The LC50 and LC90 values of the S. rarak fruit extract were greater than the LC50 and LC90 values of $A$. conyzoides leaf extract, this indicates that $A$. conyzoides leaf extract is more efficient in controlling $M$. persicae M. persicae. Determination of LC50 and LC90 values aims to see / determine the best extract concentration in killing / controlling $M$. persicae. In this study, $A$. conyzoides leaf extract and $S$. rarak fruit were very effective in controlling $M$. persicae. A. conyzoides leaf extract, S. rarak fruit extract and a mixture of $A$. conyzoides leaf extract and S. rarak fruit extract have high killing power, because the chemical content of each plant can affect the nervous system, hormonal balance, reproduction, behavior in the form of rejection. , food withdrawal, and the respiratory system. According to Soesanthy (2013), terpenoids, steroids, flavonoids, alkaloids, and saponins are repellent, affecting insect behavior, and can even cause death. These compounds are believed to influence the behavior and physiology of insects (Dadang and Prijono, 2008). Yanuar and Prijono (2013) reported that the saponin content in $S$. rarak fruit can kill pests up to $100 \%$ mixed with piper fruit.. 


\section{CONCLUSIONS}

The results showed that the most effective application in controlling the pest of $M$. persicae was a combination of a mixture of $3 \% A$. conyzoides leaf extract and $3 \% S$. rarak fruit extract with the highest mortality value of $96.14 \%$ until the 4th day, so it was necessary to re-spray it. From the research description, it is necessary to spray again with the $A$. conyzoides leaf extract and the $S$. rarak fruit extract three times with details on the 1st, 5th and 10th days with the same concentration.

\section{REFERENCES}

Astriani, D. (2010). Pemanfaatan gulma Babadotan dan Tembelekan dalam pengendalian Sitophillus spp. pada benih jagung. Jurnal AgriSains, 1(1).

Dadang dan Prijono. (2008). Insektisida Nabati: Prinsip, Pemanfaatan, dan Pengembangan. Departemen Proteksi Tanaman. Bogor. 163 hlm.

Dafrinal, R. Widiana dan A. Lusi. (2012). Kepadatan Populasi M. persicae (Myzus Persicae) dan Predatornya (Monoshillus Sexmaculata) pada Tanaman Cabe (Capsicum Annum) Dikecamatan Kotoparik Gadang Diateh Kabupaten Solok Selatan. Progam Studi Pendidikan Biologi Dan Ilmu Pendidikan STKIP PGI Sumatra Barat.

El-Khawas, S. A. M., \& El-Khawas, M. A. M. (2008). Interactions between Aphis gossypii (Glov.) and the common predators in eggplant and squash fields, with evaluating the physiological and biochemical aspects of biotic stress induced by two different aphid species, infesting squash cabbage plants (No. RESEARCH). Australian Journal of Basic and Applied Sciences 2(2): 183-193

Gainge, M. \& S. Ahmed. (1988). Handbook Of Plants With PestControl Properties. John Wiley \& Sons. Inc. Canada. $470 \mathrm{P}$.

Herlinda, S., Irwanto, T., Adam, T., \& Irsan, C. (2009). Perkembangan populasi Aphis gossypii Glover (Homoptera: Aphididae) dan kumbang lembing pada tanaman cabai merah dan rawit di Inderalaya. Seminar Nasional Perlindungan Tanaman, Bogor 56 Agustus 2009. Lembaga Penelitian, Universitas Sriwijaya.

Heyne K. (1987). Tumbuhan Berguna Indonesia (Terjemahan Dari De Nuttige Planten Van Ned- Indie). Jilid II. Badan Litbang Kehutanan Jakarta, Penerjemah. Jakarta: Yayasan Sarana Warna Jaya.

Kinasih, I., Supriyatna, A., \& Rusputa, R. N. (2013). Uji toksisitas ekstrak daun babadotan (Ageratum conyzoides Linn) terhadap ikan mas (Cyprinus carpio Linn.) sebagai organisme non-target. JURNAL ISTEK, 7(2).

Natawigena. dan Hidayat. (1993). Dasar Dasar Perlindungan Tanaman. Trigenda Karya, Bandung. Halaman 58

Oka, I. N. (1993). Penggunaan, Permasalahan Serta Prospek Pestisida Nabati Dalam Pengendalian Hama Terpadu. dalam Sitepu, D; P. Wahid; M. Suhardjan; S. Rusli; Ellyda A.W.; I. Mustika; Dan D. Sutopo 
(Penyunting). Hal. 1-10. Proseeding Seminar Hasil Penelitian dalam Rangka Pemanfaatan Pestisida Nabati. Badan Penelitian dan Pengembangan Pertanian, Balai Penelitian Tanaman Rempah dan Obat. Bogor.

Prijono, D. (1999). Prospek dan Strategi Pemanfaatan Insektisida Alami Dalam PHT.

Purba, S. (2007). Uji Efektivitas Ekstrak Daun Mengkudu (Morinda citrifolia) Terhadap Plutella xylostella L. (Lepidoptera : Plutellidae) di Laboratorium. Skripsi. Universitas Sumatera Utara. Medan. 29-35.

Purnama, W., Djamilah, D., \& Sumardi, S. (2016). Uji Efektivitas Insektisida Nabati terhadap Walang Sangit (Leptocorisa acuta T.) pada Tanaman Padi. Skripsi. Fakultas Pertanian Univesitas Bengkulu

Setiadi. (2002). Bertanam Cabei. Penebar Swadaya, Jakarta.

Soesanthy, F.S. (2013). Peranan Ekstrak Babadotan Dan Bawang Putih Serta Minyak Kemiri Sunan Terhadap Serangan Penggerek Buah Kakao. Balai Penelitian Tanaman Industri dan Penyegar

Sudarjat, S. (2008). Hubungan antara Kepadatan Populasi Kutu Daun Persik (Myzus persicae Sulz.) dan Tingkat Kerusakan Daun dengan Kehilangan Hasil Cabai Merah (Capsicum annuum L.). Agrikultura, 19(3).
Sunaryadi. (1999). Ekstraksi dan Isolasi Saponin Buah Lerak (Sapindus Rarak) Serta Pengujian Daya Defaunasinya. Tesis MS. Bogor: Institut Pertanian Bogor.

Syakir, M. (2011). Pusat penelitian pestisisa nabati dan pengembangan tanaman perkebunan. Jurnal Litbang. Jakarta

Tekeli, A. Çelik L, Kutlu H. R. (2007). Plant Extracts; A New Rumen Moderator In Ruminant Diets. Journal of Tekirdag Agicultural Faculty.

Widiastuti, D., \& Shinta, S. (2019). Uji Efikasi Ekstrak Daun Babadotan Sebagai Insektisida Nabati Terhadap Lalat Rumah (Musca Domestica) Di Laboratorium. Jurnal Litbang, Banjarnegara.

Widowati, L., (2003). Sapindus Rarak D.C. In: Lemmens RHMJ, Bunyapraphastsara N (Eds.), Plant Resources of South-East Asia, 12(3). Medicinal and Poisonous Plants. Bogor: Prosea Foundation.

Syahroni, Y. Y., \& Prijono, D. (2013). Aktivitas insektisida ekstrak buah Piper aduncum L. (Piperaceae) dan Sapindus rarak DC. (Sapindaceae) serta campurannya terhadap larva Crocidolomia pavonana (F.) (Lepidoptera: Crambidae). Jurnal Entomologi Indonesia, 10(1), 39-39.

Yolanda, K. (2013). Mengenal Pestisida Nabati. Balai Pengkajian Teknologi Pertanian. Bangka Belitung. 